\title{
The Study of Socioeconomic and Environmental Aspects of Dolomite Limestone Mining in Tuban Regency
}

\author{
Sutrisno* and Azhari \\ Economic Faculty, Bojonegoro University, Indonesia \\ (Received March 12, 2020; Accepted April 15, 2020; Published April 22, 2020)
}

\begin{abstract}
Limestone mining in Tuban Regency has serious problems due to unlicensed mining that does not comply with conservation rules and mining procedures standards. This review article aims to study the socioeconomic and environmental aspects of limestone mining in Tuban Regency. Limestone mining by the village community substantially meets the eligibility criteria. Most of them work as unlicensed or illegal miners, mining kumbung limestone as material for building bricks. They generally work for landowners or investors who have limestone management rights. Livelihoods as miners provide better welfare guarantees compared to working on agricultural land. Limestone mining activities have impacted the destruction of the natural landscape, leaving lakes, caves, or giant holes in the ex-mining limestone hills. Efforts to resolve the issue include licensing arrangements, partnerships to improve the status of illegal miners, reclamation work to control erosion, and the development of the limestone tourism business.
\end{abstract}

Keywords: dolomite, environment, limestone, mining, socioeconomic, Tuban

JEL Classification: J21, L72, Q15

\section{INTRODUCTION}

The geographical conditions in the area of Tuban Regency consist mainly of undulating areas, with various types of rocks and mineral resources found. The resources have high economic value and have intensively exploited for providing benefits, both for the community and the government of Tuban Regency. Majid \& Sukojo (2017) mapped the potential of limestone in Tuban, covering very low potential 20.27 thousand ha, low potential 45.92 thousand ha, medium potential with an area of 64.51 thousand ha, high 33.51 thousand ha and very high 32.71 thousand ha. District areas that show very high potential are Kerek, Montong, and Merakurak District, with an area of 7.42. 5.64 ha and 5.26 thousand ha, respectively.

One of the main minerals of limestone found in Tuban is calcite. This calcite deposit is the result of

* Corresponding author email: Sutrisno1@unigoro.ac.id, ISSN 2615-6075 online; ISSN 2615-6946 print @UWG Press, 2020

OJS http://publishing-widyagama.ac.id/ejournalv2/index.php/jsed/ the restructuring of crystallized limestone after passing through a dissolution process. Calcite generally formed on a bed of limestone in a period of layered crystals. Calcite can be found pure, and mixed substance depending on the mineral impurity content. Impurity minerals are formed because there is a substitution of the calcium with metal elements such as magnesium, iron, and manganese. In a specific case, calcite minerals will change into other limestone minerals, such as dolomite or ankerite.

In Tuban, a majority of the limestone minerals are dolomite. Dolomite is a variation of limestone containing less than fifty percent carbonate. Geologically, dolomite can be formed because of a primary or secondary process. Secondary dolomite occurs because of the process of dolomitization, which is the process of converting calcite minerals into dolomite. Besides, dolomite can also be formed because it is deposited separately as sediment from evaporite. In Tuban, dolomite is formed more dominantly due to dolomitization, which is the 
process of converting calcite minerals into dolomite. In general, the dolomite in Tuban is grayish-white.

The potential of dolomite minerals in Tuban has been mined by the community for generations to produce "kumbung" limestone. Kumbung is a local term that refers to limestone mined by people to make bricks. Kumbung limestone mining activities are carried out by opening mining, and mining into the bowels of the earth by making tunnel holes without regard to mining practices in a good and correct way. Mining equipment consists of mechanical and manual equipment. The land site of mining is in the authorized form of state land, certified or uncertified land, and traditional ownership land (pethok D).

Under statutory regulations, the Tuban Regency government has allocated People's Mining License to provide a place for community mining businesses in the area. In this case, the Tuban Regency government adopts the considerations of the Tuban Regency Mining and Energy Office as the regional technical implementing agency. This predetermined People's Mining Area is announced publicly and followed by the issuance of a People's Mining License. The Tuban District Government has a responsibility to manage and develop the community mining business at the People's Mining Area (Yunianto, 2015).

On the other hand, this mining activity was carried out illegally for generations to produce kumbung limestone so that mining of people in this area is very thick with social, economic, and environmental problems in the local community. Kumbung limestone or often called white limestone in Lamongan and Bangkalan regencies are dolomite minerals that are mined from hills and cut into square shapes of various sizes according to their function and use. Kumbung limestones in Tuban Regency can be used as walls and house foundations instead of bricks and river stones that cost much more than kumbung limestone.

Every activity from mining certainly has an impact on the local community, on social, economic and environmental aspects. The phenomenon of illegal limestone mining is accumulating increasingly complex problems, because it does not meet mining procedures standards, and can also invite conflicts of interest. It is the focus of this paper because the limestone mining may continue to occur if there is no significant policy to make changes.

This study aims to study the socioeconomic and environmental aspects of dolomite mineral mining and their implications for the economic development of mining in Tuban Regency.

\section{MINING RESOURCES}

Mining activities include mining and all processing activities in a particular management area. Its activities consider various environmental impacts that may arise directly and indirectly. The emergence of mining activities can encourage the development of mining services, processing industries, and other services that use mining products such as manufacturing and agriculture. The economic development in the regions is not dominated only by mining, but also by other supporting activities.

By integrating mining and processing activities, the added value of mining products can be increased. This will also have an impact on regional economic development. The government can provide special incentives to mining areas to attract more investors coming to invest. Interaction within the mining area can be developed in various partnership patterns, such as the mining pattern adopted from the people's nucleus estate, or the pattern of cooperation involving local communities.

The determination of an area to be a mining area is based on several indicators depending on the characteristics of the minerals. Mineral materials that do not require processing or are directly used generally do not have high added value, with the selling price of relatively cheap products, such as sand and stone.

Meanwhile, mining for certain minerals typically requires more sophisticated processing. Each processing process increases product added value depending on the product quantity and quality. Potential minerals that have been understood in terms of geometry, distribution, and quality are classified as reserves. Meanwhile, those of with a lower level of understanding are classified as a resource. The economic value of reserves is certainly more substantial than resources. When the potential for minerals in an area is classified as 
high or the added value is also significant, the area needs to be determined as a mining area. Sustainable development efforts need to pay attention to policies in the use of these two types of natural resources. This policy is required to maintain the quality of the environment in mining area development.

The quality of the environment is a reflection of the balanced condition of components so that they can function appropriately in sustaining the life of living things. Successful development is supported by good environmental quality. Natural resource management is a serious and ongoing effort regarding the management of scientific, ethical, and practical praxis. Degradation of natural resources is caused more by human negligence in following and applying scientific rules and human courage in fighting for ethics or moral values that have been adopted. Excessive exploitation of mining materials, without regarding to the environment, will have a negative impact in the future. Mined land will leave holes opened in the face of the earth. The environmental damage in the form of lost soil fertility and topographic changes are found in overexploited mining areas.

Mineral materials are divided into three major groups, that is metalliferous, nonmetalliferous and building or ornamental materials. In the group of metalliferous, they include gold, iron, copper, lead, zinc, lead, manganese. Meanwhile nonmetalliferous excavation consists of coal, quartz, bauxite, trona, borak, asbestos, talc, feldspar and phosphate rock. As for the excavation group, building materials and ornamental stones include slate, marble, limestone, traprock, travertine, and granite. Based on the government regulations, minerals are classified into three groups, those are (i) strategic minerals such as petroleum, liquid bitumen, earth wax, natural gas; solid bitumen, asphalt; anthracite, coal, young coal; (ii) radioactive minerals such as uranium, radium and thorium; and (iii) other materials such as nickel, cowboy, and lead.

Moreover, other mineral excavation groupings are as follow: (i) vital minerals are iron, manganese, molybdenum, chromium, tungsten, vanadium, titan; bauxite, copper, lead, zinc; gold, platinum, silver, mercury, diamond; arsen, antimony, bismuth; atrium, ruthenium, cerium, (ii) other rare metals such as beryllium, corundum; zircon, quartz crystal; cryolite, fluorspar, barite; iodine, bromine, chlorine, and sulfur. The mineral groups that are not included in these two groups but found in significant quantities are nitrate, phosphorus, rock salt, asbestos, talc, mica, graphite, magnesite; astrocytes, leucite, alum, ocher; gemstone, semi-gemstone; quartz sand, kaolin, feldspar, casts, bentonite; pumice, obsidian, pearlite, diatomaceous earth, absorbent soil; marble, slate; limestone, dolomite, calcite; granite, andesite, basalt, trachyte, clay, and sand.

\section{POLICY FRAMEWORK}

Based on Law No. 4 of 2009 concerning Mineral and Coal Mining, mining is a part or all stages of activities in the context of mineral research, management, and exploitation which includes general investigations, exploration, feasibility studies, construction, mining processes, management and refining, transportation and postmining sales, and other related activities. Mining activities to extract valuable minerals from the earth's layers have been going on for a long time. The basic concept of processing is relatively unchanged, but it is not on the scale of activities. The changes are mainly due to the increasingly economical mechanization of mining equipment and processing technology. It has caused the mining scale to be getting bigger and more intensive so that the excavation of the earth's layers is getting wider and deeper.

Based on the 1945 Constitution Article 33 paragraph (3) which states that the earth, water, and natural resources contained therein are controlled by the state and used for the greatest prosperity of the people. The Law No. 4 of 2009 includes the primary, thought that minerals and coal as non-renewable resources are owned by the state, and the development and utilization carried out by the government and regional governments together with companies. The government then provides opportunities for Indonesian legal entities, whether cooperatives, individuals, or local communities to exploit minerals based on licensing mechanisms.

In line with regional autonomy, local governments have authority in the context of implementing decentralization and regional 
autonomy, including mining management. Mining management is carried out based on the principles of externality, accountability, and efficiency involving the central and local governments. The mining business must provide maximum economic and social benefits for the welfare of the people. The management of the mining business must be able to accelerate regional development and encourage economic activities of the community or small and medium entrepreneurs, and increase the growth of mining supporting industries in the sustainable development framework. Furthermore, mining business activities are carried out due regard to the principles of accountability, transparency, and community participation.

Laws and sanctions are needed by seeking law enforcement and encouraging mining businesses to carry out community development by local conditions. Institutions approach encourage the mining business to implement environmentally friendly governance, to seek integrated actions involving traditional, small, medium, and large scale actors through mutually beneficial partnerships.

Legal and institutional socialization is carried out optimally to business people in the mining sector. They are encouraged to operate a partnership and cooperation pattern to accommodate the pattern of Smallholder Mining and Small Scale Mining under the needs of the region. The government can facilitate the partnership program with assistance, guidance, and business development subsidies. In addition, the government can allocate shallow and/or secondary (alluvial) mineral reserves in rivers or former rivers for processing by the community through small-scale mining. The government can work with private mining companies and state-owned enterprises to carry out intensive guidance and supervision within the framework of sustainable mine management.

\section{PROBLEMS AND ISSUES ADDRESSED}

\section{The Socioeconomic Aspect}

Certain geographic and demographic factors will determine the socioeconomic conditions of the community in livelihood choices to improve their welfare. The socioeconomic aspects include changes in income, business opportunities, and patterns of labor. It also includes increased demand for facilities such as housing, schools, and recreational facilities.

The limestone mining activity in Tuban is developing very significantly. Abundant limestone resources encourage many people and other parties involved to seek economic benefits from these natural resources. This condition has encouraged agricultural laborers and farmers to seek new employment opportunities. In the last 20 years, the community around the mining site, which initially worked as farm laborers, changed the jobs to become limestone miners in mining kumbung limestone for brick or house building. Their social life has changed very markedly. Working hours as a miner are seven hours every day and six working days in one week (Rifa'i \& Murtedjo, 2018).

The economic conditions of the people have changed significantly. The community income has increased markedly, showing an increase from 60 to 80 thousand rupiahs per day, or the equivalent of 2.08 million rupiahs per month. The fixed income from mining causes the family economy life fulfilled; children's education is increasingly considered and experiences real progress. Social relations are more dynamic and intensive because they often meet in the same workplace. The condition of the residence or house becomes more comfortable, in which they previously used brick walls, then they have used the bamboo wall lately (Rifa'i \& Murtedjo, 2018).

The communities in mining activities are people who are involved in small-scale mining activities. They are a community of residents that generally have a close relationship with the people's mining business in the area. They carry out limestone mining activities individually, or in groups, or together with certain business groups. Most of them work without holding formal permits or as illegal miners (Khosiah, 2014). They work as miners for landowners, mine owners, or investors who have limestone management rights, including marketing limestone to consumers.

Local people carry out limestone mining without using planning, competence, and standard mining procedures. They use mechanical equipment, digging limestone, as desired without following controls of existing provisions. Some miners did not 
comply with the technical guidance of officers from the Tuban district government. With the increasing number of unlicensed kumbung limestone miners, this has resulted in severe damage to the land and environment around the mining area. The damage that occurs in the mining area will get worse because it is not followed up with reclamation efforts by the mineworkers, mining owners, and government.
The policy of addressing the problem of miners without permission is faced with a dilemma. The socioeconomic background of the miners is people who do not have access to other economic resources because of their limited education, expertise, and skills. Closing mining sites will even create unemployment in a large number of people. Encouraging them to return to rural life is impossible while they are also not ready to work in other work fields.
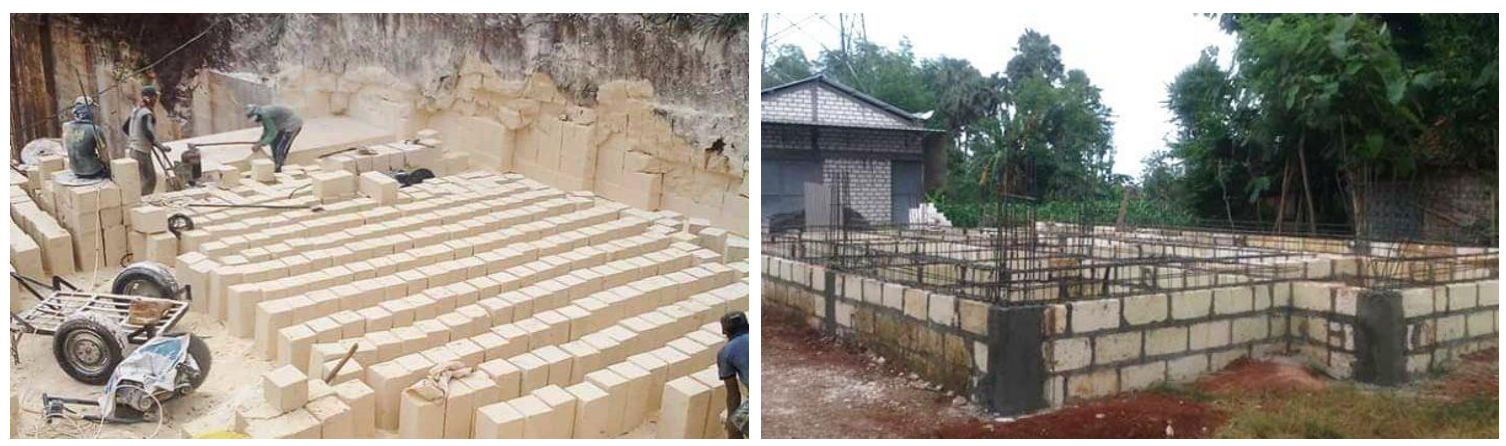

Figure 1. Processing of kumbung limestone as as building bricks in Rengel district, Tuban Regency (Source: left: https://lapak-properti.com/; right: https://batukumbongtuban.com/)

The life of unlicensed mining also faces the opportunity of extortion practices by certain individuals. The person exploits illegal miners to get rent for personal gain. It is also a part of the bad practice of government bureaucracy or ganging up with thugs. This practice continues to haunt the lives of illegal miners with certainties that make them dependent on the grip of unscrupulous individuals.

Given the recent development, it is estimated that in the next less than 50 years, limestone deposits will run out, and it will negatively impact on the social and economic conditions. The impacts will much affect them who depend on mining activities, where they will lose their livelihood as a result of the cessation of mining operations.

The large number of heavy vehicles passing by used to transport limestone has an impact on the activities of other road users. It corresponds to the increasing number of accidents, the increasing cost of maintaining bridges and roads. Trucks and vehicles used to transport limestone exceed the ability of the road to support, over time, the road becomes damaged and the life of the road becomes shorter than expected.

The negative effect on the social structure of the community around mining companies is the conflict between people. Land conflicts often occur between people directly involved in mining and non-mining communities. People directly involve in mining show loyalty to their business and try to maintain it. They give a lot of compensation or certain contributions in social life to maintain their position. This can lead to discrimination or certain privileges in some people. The society also shows a shift in life patterns in consumption behavior. Those who receive benefits from mining and get high incomes demonstrate over-buying consumer goods. Then, their lifestyle has changed more consumptive, leading to social jealousy, moral hazard, and disharmony.

\section{The Environment Aspect}

Mining activities have a large force of environmental change, both before and after 
mining, including the impact on the local environment and the greater area. The situation of limestone quarrying before mining is infertile, which is a stretch of dry land that has a thin topsoil layer on the limestone stand. Limestone mining activities cause land destruction from land with growing media and natural biodiversity into irregular land with very unproductive conditions. The environmental damage of the limestone mining process would remove the topsoil layer, reduce fertility, reduce microbial diversity, and eliminate the vegetation that grows above it (Andriani, Kurniahu, \& Sriwulan, 2019).
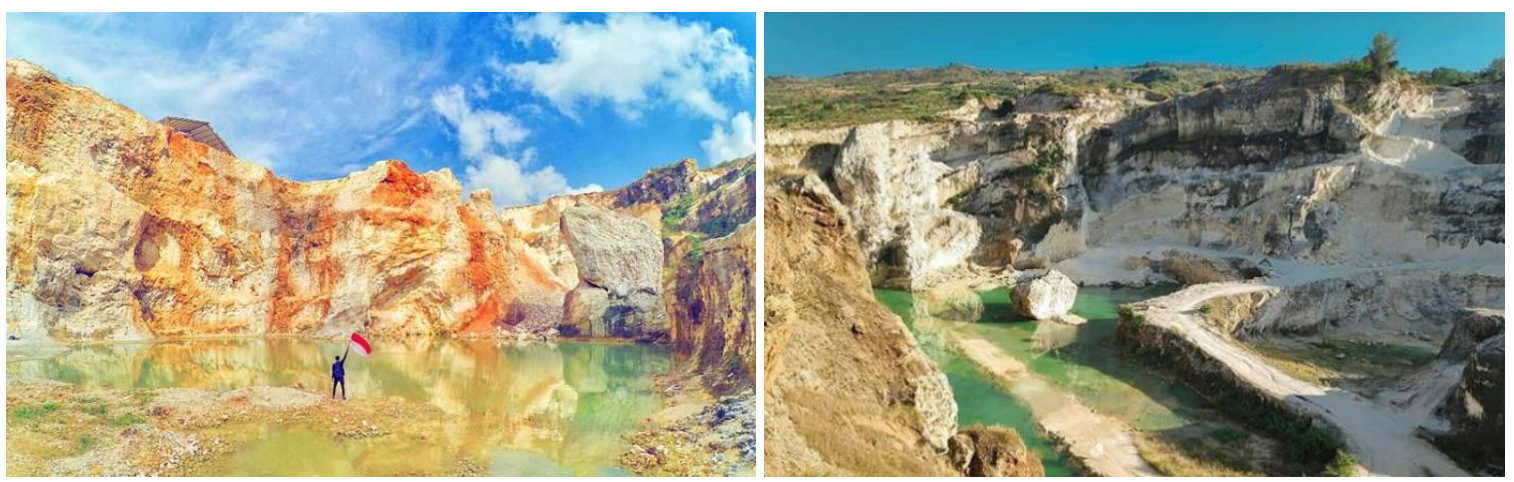

Figure 2. Mining site of limestone in Rengel district, Tuban Regency (Source: left: https://wisatalengkap.com/; right: @telkomsel.lamongan)

The environmental impacts of limestone mining activities are very remarkable such as dust pollution and road damage. The mining process can indeed harm the environment and public facilities of a region. The dust pollution can affect eye visibility and respiratory problems in communities around the mining environment (Nadiva, 2017; Tolinggi et al., 2014). Besides, dust pollution can also disturb road users and reduce the visibility of drivers so that it can cause traffic accidents. Trucks used to transport minerals exceed the ability of the road; over time, the road will be damaged, and the life of the road shorter than expected. The use of fuel in vehicles or large engines in mining has led to an increase in air pollution (nitrogen dioxide, sulfur dioxide, carbon monoxide), which can cause various environmental problems.

Water pollution due to the limestone mining process is not significant. The use of water in the process of cutting limestone is minimal, sometimes used by miners to cool sawtooth when cutting stone. The remaining drainage then seeps into the soil, dissolves into rock minerals, and it has no effect significantly on the biological life. There is no significant mineral waste found in the mining process.
Limestone mining in Tuban leads to a significant change in the topography of the mining area. It also causes the lower of the ability of water recharge areas that lead to the groundwater reserve. The mining activities reduce the ability to recharge areas to more than 31 million liters per year (Adi, Prakoso, Rizqiani, \& Utama, 2014).

Lime mining activities in Plumpang Subdistrict, Tuban Regency are prone to causing landslides that endanger mining workers. The damage is getting worse because there is no attempt to carry out reclamation. Mining impacts on the destruction of nature and land change the natural landscape. The hills are destroyed, leaving the excavation of the former mine. The extent and depth of the exmining of limestone quarry indicate variations depending on the level of exploitation. In Sumberagung, the former quarry has reached 298 $\mathrm{m}$ in length, $177 \mathrm{~m}$ in width, and $54 \mathrm{~m}$ in depth. Sumberagung Village is the area with the most extensive former excavation. They just leave the ex-mining area and look for new land for mining activities (Khosiah, 2014). In the rainy season, the excavation is filled with rainwater creating lakes that are very likely to endanger workers or cause landslides. 
Furthermore, the damage caused by kumbung limestone mining also left a significant problem. At the end of periods, the activity of mining nonlimestone in the crevices of the earth's interior also occasionally happened. This process of exploitation creates giant caverns or structures that are sensitive and harmful to humans. This structure is a high risk of erosion or vibration of the earth's surface and can collapse the cave space at any time. This damage is permanent and cannot be rehabilitated for all time.

\section{POLICY RECOMMENDATION}

Tuban Regency is an area that is quite rich in its natural resources. The potential of natural resources of dolomite minerals mining certainly has a positive impact on the welfare of the mining community and society in general. The existence of mining has been able to encourage and move economic activity in the region. The management of mining activities is expected to increase economic growth, accelerate the pace of regional development and distribution of benefits from mineral resources.

This mining activity requires a regulatory framework in terms of integrated planning from the initial stage to post-mining. It should be understood that all party is necessary to comply with all provisions, including institutional rules, environmental impact analysis, competency standard and mining procedures, rehabilitation to post-mining land-use plans. The basis of this plan and implementation should be done, given the nature of the change that occurs in mining sites.

The policy framework for limestone mining management is compiled comprehensively, referring to the achievement of benefits in the socioeconomic and environmental aspects (Jolo \& Gautama, 2018).

\section{The Licensing Arrangement}

The government has an essential role in regulating the management of mining to produce benefits, especially in the district of Tuban Regency. The government ensures that mining activities do not negatively impact on socioeconomic and ecological life, at present or in the future. Licensing arrangements are an entry point for achieving management objectives.
The government should strictly select mining holders who meet the applicable provisions. It corresponds to regulatory, especially the Law on environmental impacts, has evolved since the enactment of Law no. 4 of 1982, Law No. 23/1997, and Decree of the Minister of Mines and Energy No. 389K/008/MPE/1995 concerning Technical Guidelines for the Preparation of Environmental Management Efforts and Environmental Monitoring Efforts.

Licensing regulation procedures are managed in a transparent and straightforward process in good governance mechanisms. Mining permit holders fulfill the mandatory list of Environmental Management and Monitoring Efforts. Based on Tuban Regency regulation Number 19 of 2011 concerning Mining Business Permits, the potential for dolomite community mining activities generally meet the criteria. The mineral reserves in the form of dolomite limestone are found in the highlands and lowlands.

The licensing arrangement considers the development of technological innovations, proper and correct mining practices, well-integrated mining systems from upstream to downstream, as well as the community participation. The community social approach aims to realize the implementation of structural transformation, the people's mining area and small scale mining program, and a partnership program between illegal miners and the established holding company.

In the final stage, law enforcement needs to be considered under the procedures and stages of persuasive steps that are technically coordinated by the Tuban Regency Mining and Energy Office.

\section{The Structuring of the Mining Area}

The structuring of the mining area aims to ensure that mining activities, supporting activities, as well as human and ecological life, can help each other and benefit all stakeholders. Structuring covers the main mining areas (including exploration or quarry zones), processing facilities to increase the added value of mining products, physical infrastructure (such as roads, electricity, telecommunications), and non-physical networks (such as regulations and permits). The arrangement of the outside of the main residential 
area includes infrastructure facilities and areas for other socioeconomic activities.

Structuring involves comprehensive planning, including efforts to accommodate human needs and behavioral actions to ensure human survival and well-being. Structuring also provides opportunities for efforts to limit mining areas, maintain ecosystems, and control environmental management activities from the impact of mining activities. Structuring also gives a space for reclamation activities to restore the condition of ecological damage, and maintain biodiversity.

In general, the limestone mining environment is not based on a comprehensive arrangement. Local people typically find mining areas. Since then, the government usually intervenes to regulate its management. That is why the main mining area and the area outside it do not show adequate configuration. This creates a high risk in or outside the mining environment. Logistics needs, people, and various interests flow irregularly beyond infrastructure capacity and often create congestion and accidents around the mining area.

In Sukabumi, limestone is exploited by residents without proper management and control. Residents face health risks from exposure to limestone mining. There is only about $9 \%$ of Padabeunghar residents are safe from the health risks of dust particles during their lifetime. According to Indonesia's national ambient air quality standards (PP 41/1999), the mining location is a minimum of $3 \mathrm{~km}$ from a residential area. The efforts to control dust particles at safe levels can be achieved by reducing production from 25 tons/day to 6.3 tons/day, or by moving the limestone furnace to places far away (Suryaman \& Rahman, 2011)

Structuring has considered the potential of limestone quarries at a location. From the potential amount of limestone, it can be predicted how much is the production of limestone, the duration of mining concessions, the scale of the production economy, technological innovations developed, and plans for reclamation and rehabilitation efforts. This business scale description needs to be taken into consideration in the licensing process. Mining technology developments also tend to be more advanced and economical. This brings mining to the wider and deeper layers of the earth, so consideration needs to be placed on mining restrictions. The point of view of ecosystems and natural landscapes becomes more critical so that limestone mining activities do not only emphasize the economic aspects.

\section{The Management Partnership}

The mining business is intended to contribute to the welfare of the community. Communities directly involved in mining must work together and show a role to support sustainable mine management. According to Yudhya (2018), the business performance of the limestone mining industry in East Java is considered ineffective. This condition is caused by the improper implementation of innovation management and partnerships. This has been the main concern in the preparation of this article. This is also a challenge for the limestone mining business, and this requires careful consideration of the socioeconomic and environmental aspects.

The main responsibility of mine management is to increase the dignity of the limestone miners. The efforts to resolve this problem will lead to the more responsible management in term of environmental conservation in the mining area. This social approach needs to be done by taking into account the institutional framework starting from the licensing process to post-mining activities. This will also indirectly solve the complex problems of the existence of unlicensed miners and the various conflicts that correspond to it.

Private mining companies and state-owned companies or regional governments are encouraged to work together with individuals or groups of mining communities through a business partnership system. The mining company gradually carry out the mentoring process to implement mining procedures, management standards, as well as educate on the conservation of mining areas. Miners without a license operate within the concession area of a mining company under certain conditions that are mutually beneficial, under intensive guidance and supervision.

Mining companies continue to carry out socialization about the importance of a social approach while providing opportunities for people to play a direct proportional role in mining business 
activities without ignoring the principles of good and right mining.

Residents who are not directly involved in mining also have the opportunity to provide a role in supporting the limestone mining business. They can play a role in helping small businesses, such as trade, transportation, and other needs. They also get management assistance and technical guidance to improve business performance.

Prominent figures in the villages are involved in the process of planning and implementing of the limestone mining. They are also more engaged responsibly in the scope of mining activities following environmental conservation rules. The role of these figures, such as scholars, local government officials, or pioneer youths, can be a dynamic glue to maintain social life against opportunities for conflict (Rokhmad, 2020).

\section{The Reclamation}

This reclamation is intended to recreate an environment conducive to the survival of flora and fauna, and human life around the limestone quarry. Reclamation activities are part of management responsibilities by miners both companies and individuals.

Most limestone mining businesses leave traces of dugouts, giant holes, drainage channels, and damaged natural expanses. This condition should be protected and conserved so as not to cause more damage or endanger human activities.

The weather conditions of tropical plains such as Indonesia have two opposite sides. The first side of the high rainfall and humidity can accelerate the growth of biodiversity. At the same time, it also produces tremendous erosion and weathering strength. This is very dangerous because it can damage the structure of giant holes and mining excavations. These two things are the primary considerations in the reclamation effort.

The ecological impact of the post-mining activities spurred to be considered first. Spatial planning is required to be done thoroughly. If it is not, mine closure will only leave damage to the landscape and the environment. Given this reason, it is necessary to address environmental impacts and damage during operations as well as after the closure of the mining business in a sustainable manner. Reclamation is an effort that can eliminate the impact of mining activities by implementing a large design (one goal and many steps) and a chronology of the mining activities affected based on an environmental impact assessment study.

Reclamation experience in mineral mining areas such as gold, manganese, and iron sand in Halmahera (Jolo \& Gautama, 2018) is carried out by preventing abrasion through planting mangroves, cultivating coral reefs; establishing protected areas and strengthening conservation status to protect endemic bird species; limiting permits for coastal exploitation; and empowering the fishing community.

The efforts to control erosion in ex-limestone quarried land need attention. This can be done by replanting local plants to prevent landslides. On limestone beds, topsoil containing nutrients can be used to fertilize the ex-mining land. The limestone base element can support the fertility of the soil to grow vegetation assisted by the provision of water in creating moisture microclimate.

Naturally, pioneer plants can grow to replace lost plants. Pioneer plants can be used as a reference for land restoration because these plants can grow on degraded land by means of Rhizobacteria Promoting Plant Growth (PGPR). Also, the presence of pioneering plants can inhibit soil erosion due to the ability of the roots to hold the soil from scours. There are five types of plants with the highest INP, namely Lamium barbatum, Chromolena odoratum, Tridax procumbens, Waltheria indica, and Digitaria sanguinalis (Andriani et al., 2019).

\section{The Development of Tourism and Other Services}

The efforts of the Tuban Regency government in managing the limestone quarry and its problems are carried out within the framework of economic structural transformation. This effort was carried out in stages to direct the economy towards activities rather than agriculture and mining. The economic activities of the local community are directed towards business activities in other sectors that are more attractive than the mining sector activities. This policy is supported by the allocation of management assistance and subsidies from the government. 
The natural potential of limestone hills also provides opportunities for tourism activities. The exotic limestone hills can lead to tourism services, both on ex-mining land and natural limestone. The government also pay much attention to this. The tourism business is believed to provide higher added value including environmental conservation education, and to increase the dignity of the local population with the ability to serve tourist services (Nugroho, Hanafie, Negara, \& Yuniar, 2020; Nugroho, Negara, \& Yuniar, 2018).

The utilization of ex-limestone quarry land for tourism is carried out in Bukit Jaddih, Bangkalan, Madura. Tourism activities have succeeded in creating jobs, developing food stalls, and triggering cellular network infrastructure in tourist areas, which are also rural areas. Limestone hill tourism requires management support to ensure cleanliness, safety, protection, and comfort in the area of the former limestone quarry (Parmawati, Imaniyah, Rokani, Rajaguni, \& Kurnianto, 2018).

Tourism activities require considering in-depth analysis to be the first choice compared to mining activities. This decision can be applied to limestone hill management plans that are sensitive to conservation threats. This perspective can be used by local government to attract investors to develop tourism rather than mining activities. The results of the study conducted by Nadiasa et.al (2006) shows that an economic feasibility analysis of tourism investment in Jimbaran limestone hill (Garuda Wisnu Kencana project) found a NPV (net present ratio) of 116.2 billion rupiahs with an IRR (internal rate return) value of $20 \%$, and a BCR (benefit cost ratio) value of 1.20 .

\section{CONCLUSION AND SUGGESTION}

Based on the Regional Regulation number 19 of 2011 concerning Mining Business Permits, the potential for limestone mining by the general public meets the eligibility criteria. Dolomite minerals dominate the type of limestone in Tuban district.

The community manually operates the main area of limestone mining. Most villagers work as unlicensed or illegal miners. They work and cut the kumbung limestone as material for building bricks. They work as miners for landowners or investors who have limestone management rights, including marketing limestone to consumers.

Economically, livelihoods as miners provide a guarantee of survival and welfare compared to working on the agricultural land. Moreover, they have savings to finance children's education, build houses, and buy motorized vehicles.

In the environmental aspect, limestone mining activities leave behind mined excavations, caves, or giant holes in the ex-mining limestone hills; and damage the natural landscape. This management practice has damaged the ecosystem and has the potential to create erosion and endanger human safety.

Policy recommendations to improve the performance of dolomite limestone mining in Tuban are carried out through the efforts as follows: (i) licensing arrangements emphasizing on sustainable mining standards, (ii) structuring or limiting excavation areas to preserve ecosystems, (iii) creating collaborative management to upgrade the status of illegal miners, (iv) doing reclamation work to control erosion and ( $v$ ) developing of limestone tourism business.

\section{REFERENCES}

Adi, P. I., Prakoso, W. G., Rizqiani, P. I., \& Utama, W. (2014). Impact of Topographic Change against Groundwater Recharge Areas Caused by Limestone Mining in Rengel District, Tuban Regency. Procedia - Social and Behavioral Sciences, 135, 25-30. https://doi.org/10.1016/j.sbspro.2014.07.320

Andriani, R., Kurniahu, H., \& Sriwulan, S. (2019). Inventarisasi Tumbuhan Pionir Lahan Bekas Tambang Kapur Di Kecamatan Rengel Kabupaten Tuban Jawa Timur. Biotropic: The Journal of Tropical Biology, 3(1), 56-61. https://doi.org/10.29080/biotropic.2019.3.1.56$\underline{61}$

Jolo, A. Y., \& Gautama, R. S. (2018). Pengelolaan dan Pemanfaatan Sumber Daya Mineral Berwawasan Lingkungan (Studi Kasus Kabupaten Halmahera Utara). TECHNO: JURNAL PENELITIAN, 7(01), 128. https://doi.org/10.33387/tk.v7i01.355

Khosiah, N. (2014). Dampak Penambangan Batu Kapur Terhadap Kerusakan Lingkungan di kecamatan Plumpang Kabupaten Tuban. Swara Bhumi E-Journal Pendidikan Geografi FIS 
Unesa, 3(3), 137-143. Retrieved from https://jurnalmahasiswa.unesa.ac.id/index.php/ swara-bhumi/article/view/8952

Nadiasa, M., Gede, I., Diputra, A., \& Yansen, W. (2006). Investment Analysis in The Development of Taman Budaya Garuda Wisnu Kencana in Regency of Badung. Jurnal Ilmiah Teknik Sipil, 10(2), 167-176. Retrieved from https://ojs.unud.ac.id/index.php/jits/article/view \$3436/2470

Nadiva, A. S. Z. (2017). Aktivitas Penambang Batu Kapur (Saren) Di Desa Leran Kulon Kecamatan Palang Kabupaten Tuban. AntroUnairdotNet, 6(1), 39-49. Retrieved from http://journal.unair.ac.id/download-fullpapersaunc31682f69afull.pdf

Nugroho, I., Hanafie, R., Negara, P. D., \& Yuniar, H. R. (2020). Local Capacity Building in the Ecotourism Development. International Journal of Innovative Technology and Exploring Engineering (IJITEE), 9(35), 224-228. https://doi.org/10.35940/ijitee.C1049.0193S20

Nugroho, I., Negara, P. D., \& Yuniar, H. R. (2018). The Planning and The Development of The Ecotourism and Tourism Village In Indonesia: A Policy Review. Journal of Socioeconomics and Development, $1(1)$, 43-51. https://doi.org/10.31328/jsed.v1i1.532

Parmawati, R., Imaniyah, A., Rokani, L. E., Rajaguni, M. I., \& Kurnianto, A. S. (2018). Ecotourism Development Strategy of Bukit Jaddih Karst, Madura. J. Ind. Tour. Dev. Std, 6(2),

113-119. https://doi.org/10.21776/ub.jitode.2018.006.02. $\underline{06}$

Rifa'i, A., \& Murtedjo. (2018). Kajian Sosial Ekonomi Penambang Batu Kapur Di Kecamatan Palang Kabupaten Tuban. Swara Bhumi. Retrieved http://jurnalmahasiswa.unesa.ac.id/index.php/s wara-bhumi/article/download/25591/23460

Rokhmad, A. (2020). Configuration and the role of community leaders in the conflict of natural resources of limestone mining for the cement industry in Rembang Indonesia. International Journal of Energy Economics and Policy, 10(2), 521-528. https://doi.org/10.32479/ijeep.8321

Suryaman, U. S., \& Rahman, A. (2011). Wilayah Aman Bagi Pemukiman Dekat Tambang Batu Kapur: Suatu Pendekatan Manajemen Risiko. Jurnal Ekologi Kesehatan, 10(4), 256-266. Retrieved from http://ejournal.litbang.kemkes.go.id/index.php/j ek/article/view/3818/3670

Tolinggi, S., Nakoe, M. R., Gobel, A., Sengke, J., Keman, S., Sudiana, K., ... Azizah, R. (2014). Effect Inhaling of Limestone Dust Exposure on Increased Level of IL-8 Serum and Pulmonary Function Decline to Workers of Limestone Mining Industry. International Refereed Journal of Engineering and Science, 3(8), 66-72. Retrieved from http://www.irjes.com/Papers/vol3-issue8/Vesion 1/J386672.pdf

Yudhya, R. R. (2018). The effect of partnership and innovation management on business performance of a limestone mining company in East Java. International Journal of Business, 23(3), 261-269. Retrieved from https://www.questia.com/library/journal/1P42183072680/the-effect-of-partnership-andinnovation-management

Yunianto, B. (2015). Allocation of the Artisanal Mining Area: The Case of Dolomite Mining in District Palang-Tuban Regency. Jurnal Teknologi Mineral Dan Batubara, 11(1), 29-48. Retrieved from

https://jurnal.tekmira.esdm.go.id/index.php/min erba/article/download/240/152 